\title{
"NORWAY IS LIKE A HOSPITAL." VEHICLES FOR (RE-)CONSTRUCTING THE NATIONHOOD AMONG POLISH IMMIGRANTS IN OSLO
}

\author{
CONFESSION: NATIONALITY \\ AND THE STIGMA DILEMMA
}

I $\mathrm{n}$ the important essay on the ethical aspects of anthropologist's work, Clifford Geertz points out that: 'The outstanding characteristic of anthropological fieldwork as a form of conduct is that it does not permit any significant separation of the occupational and extra-occupational spheres of one's life. On the contrary, it forces this fusion. One must find one's friends among one's informants and one's informants among one's friends; one must regard ideas, attitudes, and values as so many cultural facts and continue to act in terms of those which define one's own commitments; one must see society as an object and experience it as a subject' (Geertz 2001: 39). In fact, I have been always a keen adherent of this thought, despite some of the utopian and romantic ideas that it carries; or maybe it was because of them, that I found it significant. Nevertheless, the idea of being constantly in the 'field' was clearly the essence that, in my opinion, defines the specifics of anthropological perspective. However, I have to confess that my attitude to the very reflection had been put to a series of tests, while I was conducting a fieldwork among Polish immigrants in Oslo*. It lucidly occurred to me that my informants are not my

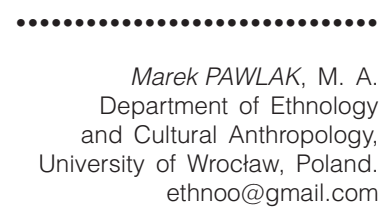
ethnoo@gmail.com .....

I conducted an anthropological fieldwork among Polish economic immigrants in Oslo in the summer 2009 for the interdisciplinary academic project CULCOM ('Cultural Complexity in the New Norway') supervised by Thomas Hylland Eriksen. The fieldwork involved the participant observation and narrative interviews among Poles who live and work in Oslo. Therefore, the main aim of the fieldwork was to examine the vehicles for reconstructing the nationhood in immigrants' everyday life, as well as the specific nationalism that is in a way directed by social and economic class, gender relations and particular cultural background. The present article is merely the general ethnographic glance at the complex issues of Polish immigrants practices in Norway. 
friends in Clifford Geertz's terms; what is more, I did not even wish them to be ones. The participant observation was not merely exhausting in physical terms, but it also started to interfere with all levels of my identity. Obviously, one may notice that there is nothing extraordinary in such an experience. After all, the 'fieldwork crises' is a very often issue among all engaged anthropologists since Bronisław Malinowski. The physical exhaustion and nostalgia, even the distaste of the informants are, however, the basic aspects of the fieldwork. Yet, it is noteworthy that the symptoms of the 'crisis' are often used only as a rhetoric figure just to authenticate the article, whereas, in some other cases they really may be an issue for anthropologist's work.

Nevertheless, I believe that my own experiences from the 'field' were slightly different. In fact, I would be far from describing my particular attitude to the fieldwork and informants in the anthropological terms of the 'crisis'. I would rather point out that, while I was balancing between Polish immigrants and Norwegian society, I had a sort of a stigma dilemma, which was obviously related to the nationality phenomenon. Therefore, the crucial issue was that the reasons of my dilemma involved not only Poles I met there, lived with and interviewed, but also the specific social and cultural role that was in a way imposed upon me that time by Norwegian society. Whilst living and sharing everyday life with Polish immigrants in the Tveita district of Oslo, I realised how huge an impact the 'field' had on my own nationality perception. After all, it was not the usual and common fieldwork experience for me. In fact, I was not only the participant observer in anthropological terms, I was also 'one of them' in the context of nation belonging. Clearly, I had a similar cultural background and collective experience as my informants. Therefore, knowing all the details of their daily routine, made me believe that there is a narrow and unambiguously negative image of Polish immigrants among Norwegian society. On the other hand, it was hard not to believe in that, when rudeness and vulgarity, women treated like objects not subjects, racial prejudice were everyday occurrences, thus reflecting the world-views of my informants. In other words, it quickly occurred to me that the 'Tveita world' may be the general, but also superficial, image of Poles living and working in Norway. Consequently, my identity began a constant struggle and the fact that I was in a way balancing between two different realities only intensified the very experience.

Although I did not want to be stigmatised due to my nationality in everyday interactions, it was almost impossible to avoid. Unknowingly, I got dragged into the specific immigrant network of arrangements, connections and praxis. In other words, I was enculturated to 'be', to 'feel' and to 'act' like an immigrant from the first day I arrived. This very state of belonging, in turn, quickly affected my own daily routine, which I constantly attempted to question. I even began to be ashamed of my own nationality. For example, I felt uncomfortable speaking Polish on the phone, whilst I was in a metro station; I was literally crossing the street, when I saw two Poles arguing about some construction tools, just to avoid them; finally, I was paying attention to all small details that could reveal my 'Polishness'.

The paradox was that the more I attempted to escape from the yoke of nationality, the more I felt stigmatised by it. The most banal and everyday situations and actions made me realise how strong the national identity may be. For example, obviously there was nothing unusual in buying the low-price products in the supermarkets, especially for me - an anthropologist on an academic grant. But in a wider context I have realised that I was simply following the tips, clues and guides that I have received from my infor- 
mants. I knew what to buy and where to buy, because I was told so before. Therefore, the various contexts of everyday life constantly revealed the specifics of the immigrant knowledge that I have acquired from the Polish immigrants. Consequently, it was difficult to separate the subjective national experiences and misconceptions of the daily routine, from the very ethnographic work and observations of the immigrants' life. Hence, the headnotes, the fieldnotes and the diary that I kept, began to mutually pervade. I even caught myself in the act of making the fieldnotes in the metro station, while I was coming back from a construction job, that my informants offered me, and which I accepted for the purpose of anthropological observations. In fact, 'making the fieldnotes' that time was a symbolic performance and a sort of personal therapy, which helped me deal with the immigrant work experience.

Therefore, the stigma dilemma was an important experience in the context of the fieldwork I have conducted among Polish immigrants. It not merely reveals the significance of nationality in the contemporary world, but also raises some crucial theoretical and research questions. For example, what does it mean to be perceived as an immigrant, even though he/she does not feel like one? How does immigrant's cultural and national background cope with the habits and praxis of the national majority? What peculiarities may one find in the context of social and cultural interactions between national minority and majority? Are the interactions merely superficial and pragmatic or do they involve any deeper significance and complexity? And finally, why are the national categories so rooted in the individual's world-view?

\section{THE NATION PHENOMENON AND THE POSTMODERN WORLD}

Many social intellectuals point out that the essence of the contemporary world may be described in the terms of liquidity, instability and elusiveness (see, for example, Bauman 2000). Therefore, the individual experiences constant relocation due to the redefinition of time and space. The postmodern daily routine seems either to lack in any boundaries or, to put it in James Clifford's terms, the very boundaries are blurred, while the individual is constantly on the move. Thomas Hylland Eriksen asserts that:

\footnotetext{
Although it sounds hyperbolic to say that 'we are all on the move', it is true in several senses that movement is characteristic of contemporary globalization. Tourists, business and conference traveller, refugees and migrants: there are more of them than ever before. There is a sense in which boundaries that may have been considered firm and reliable in the mid-twentieth century are dissolving (Eriksen 2007: 92).
}

However, despite the principles of postmodern reality, or even due to some of its aspects (for example, interculturality and the common experienced category 'us and them') the boundaries of nations and nationalities, are still reproduced. It is not an issue of merely global politics and ethnic struggles, but also a significant element of the daily experienced routine and popular culture, which are usually neglected by the intellectuals. The national identity reveals its power in the most banal and common contexts of individual's everyday life. In fact, 'the flag' - to use Michael Billig terms - is constantly 'waved' just to remind the individual that the world of nations is the 'natural' world of one's existence. Therefore, it is noteworthy that, for example, while exploring the Internet websites, one comes across different domains that are marked '.uk', '.pl' or '.no' 
and which obviously signify the nation belonging; on the other hand, while buying albums in a music stores, clearly one may experience the division of 'domestic' and 'foreign' music. Thus, there is no other world, then the world of nations. According to M. Billig, if the phenomenon of nationhood is near the surface of contemporary life,

[...] then routinely familiar habits of language will be continually acting as reminders of nationhood. In this way, the world of nations will be reproduced as the world, the natural environment of today (Billig 1995: 93).

In other words, due to the fact that the contexts of national identity performances are 'obvious' and 'natural' for the individual in the contemporary world, the very idea of nationhood as a social and cultural construct seems to be neglected and forgotten.

Yet, it is hard to be surprised and demand any other attitude from the individual. After all, Julia Kristeva (1993) points out that in the world, where the individual does not know who he/she is and where the individual even does not know if he/she really exists, then it is obvious that the individual looks for his/her own roots, for a sort of stability and clearly, the individual finds it in the nationhood phenomenon. Therefore, the nationhood may be perceived as a metaphoric harbour in the postmodern world, where the individual may anchor the identity and experience the feeling of belonging, despite the artificial and imagined nature of the nationhood. It may be even more crucial in the context of contemporary migration movements, however, it is a more complex issue that obviously involves various causes as well as social and cultural factors. Nevertheless, the individual's need for a collective experience of social and cultural constructs is therefore a significant sphere for an anthropological reflection. Namely, in the context of the nation phenomenon, nationalism and national identity performance, the importance of the anthropological perspective concerns not the question 'What is the nation?', but rather, 'How the nation is reproduced, represented and collectively experienced by the individuals?'.

Therefore, the fieldwork I have conducted among Poles reveals how significant is the process of reconstructing national identity among immigrants. The fact that I was living with my informants and sharing with them some of their everyday activities enabled me to observe the important context of national identity performing. In turn, due to the immanency of routinely repeated actions, my informants were usually unaware of their national background. I have noticed some paradoxes and ambiguities that concerned the distinction between the spheres of practicing and narrating the national identity. According to my informants 'being' a Pole deserves a special respect and pride. Everything that is specific and which may be described in terms of 'Polishness', was proudly believed by them to be important and unique. But simultaneously, I have noticed that they have serious problems with explaining and describing the term 'Polishness'. They also found it really hard to answer the question what does it mean to be a Pole? I often heard that the questions of this nature are simply impossible to answer. These difficulties are lucidly noticeable in the interviews I have recorded. The spaces of silence between words and the quandary pauses between sentences cast new light on the mentioned subject matter. They are really significant in Derridian terms and therefore should not be neglected. To realise the importance and complexity of such seemingly irrelevant details, one must approach to them from a perspective with wider context.

Here is an example of a conversation I had with one of my informants, Andrzej. We were both sitting and chatting in the kitchen while he prepared breakfast. Andrzej is 
a 40-year old man, has been living in Oslo for 7 years and is the owner of a construction company. Before coming to Norway, he spent some time working in Italy and Spain, and before that lived with his family and worked in the USA for almost 20 years. Yet, as he told me, he and his family decided to come back to Poland because they felt sort of lonely being separated from relatives and lacked any close friends. That is also why Andrzej came to Oslo alone. Knowing his biographical background I asked him the particular question: 'What does it mean to be a Pole, while you are on the constant move?'. In the beginning he seemed a little bit confused, not knowing what to say, he was just smiling. But after a short while, he finally said to me:

It is hard to say, you have to feel it. It is really hard to describe it, you know... To be honest I don't know how to answer it, but I can tell you that whichever country I've been to, I have always felt like a Pole, even though Poland had given me a hard time. And you know, this is really amusing and interesting... A man who experience so many bad things for so many times in his own country, still thinks and still feels that he is a Pole, either during a conversation or in some other different situations.

The significant fact was that while saying this, Andrzej was preparing breakfast using the Polish grocery products that he brought from home and what is even more crucial, while we were talking there was a TV switched on to a Polish channel news. Therefore, even the context of the interview was loaded with national symbols and contents, Andrzej could not clearly express the essence of his nationality. Thus, as it has been already indirectly noticed by Bronisław Malinowski, the discourse and praxis are not mutually tantamount. In other words, 'the things one says are not the exact things one does', especially in the context of the national identity, nationalism and immigrants issues. After all, the individual's perception of nationhood may be described in the terms of Husserlian Lebeswelt, therefore not merely the ethnographic interview but the whole its context may reveal the significant, but yet often neglected, details of national praxis.

\section{CULTURAL INTIMACY AND BANAL NATIONALISM AS VEHICLES} FOR CONSTRUCTING THE NATIONHOOD AMONG IMMIGRANTS

The sense of nation belonging was lucidly strong among my informants, although they themselves were unaware of the process of either symbols reproducing or national routine performing. In fact, it seemed so 'natural' and 'obvious' for them to act in this specific way, that consequently it seemed 'forgotten'. The everyday life of Polish immigrants may be then described in the terms of banal nationalism, which assumes the constant presence of nationhood in every spheres of the individual's life. Thus, the daily routine, which at first glance, seems to have secondary importance is filled with national praxis. Therefore, the habits like watching TV, preparing food and using the Internet may be lucidly perceived as vehicles for reconstructing and performing the national identity.

It has been already mentioned that the context of preparing a dinner is not merely a case of appeasing one's biological needs. Food products and particular cuisines are always permeated with national symbols and habits. Therefore, while I was observing the everyday rituals among Polish immigrants, which concerned making and eating dinner, I have realised that the products brought from Poland are not only a pragmatic matter of economy. In the very beginning I simply attributed this to the expensive stan- 
dard of living in Norway, but relatively quickly, it occurred to me that Polish products are also significant elements of national sentiment. Not only 'our' tastes better than 'theirs', as my informants maintained, but also, there is no other place in the world with a taste of bread as good as in Poland. Therefore, the 'gastronationalism', as one may call it in this context, reveals the importance of immigrants' cultural and national background, even though it seems anecdotal. It implies the immigrants' needs for 'known' and 'predictable' ingredients in the daily routine. 'Gastronationalism' is one of the elements that keeps the imagined community in the constant process of nation-reconstruction and is a primary and often unconscious vehicle for banal nationalism. Thus, I found it both interesting and humorous, while I was unpacking my bags in a Tveita flat and I heard some comments coming from my new Polish flatmates. As soon as they noticed that I came only with one bag of clothes, without any additional suitcase full of Polish food and products, they were shocked. In fact, I was perceived by them as an ignorant without immigrant knowledge; 'a guy who does not know the life in exile'. They said to me that not only will I have to spend money on Norwegian food, but also I will not be satisfied with its taste.

However, food is not the only context of reproducing national symbols and myths. There is one even greater visible space of creating the boundaries and practicing national habits in everyday life. Obviously, the Internet is a significant tool, which may be perceived and experienced in nationalistic terms. Therefore, reading daily online newspapers kept my informants updated with all the news from the homeland, whereas checking the matrimonial websites kept them entertain in the evenings. Contemporary social networks and web forums have a enormous impact on national identity and nationhood perception. Thus, Benedict Anderson's concept of 'imagined community' in printed capitalism should be redefined by adding the terms and context of cyberspace and audiovisual reality. One of the interesting aspects of using the Internet by my informants was the idea of listening to a Polish radio station. It was one of these commercial radio stations with popular music, which one may find in every country. It really puzzled me why do they listen to the particular Polish station, when exactly the same music may be heard elsewhere? Obviously it was a daily habit and a sort of routine that they developed and adhered to back in Poland. Therefore, it was a symbolic connection with the homeland. Last but not least, there was the online software that enabled them to communicate with relatives and friends. Additionally, it was also an important tool, which helped them solve different problems among themselves. For example, I recall Skype conversations concerning the bank account problems of the immigrant friend of Andrzej. They spent some time online translating the bank's website. The Internet seems therefore to be an elementary vehicle for preserving the nationhood belonging.

Another aspect of my informants' daily routine, which was loaded with nationalistic actions, concerned the ritual of watching TV. It was their usual way of spending spare time after work and, what was significant, it quickly occurred to me that it is not merely a secondary importance entertainment. There was a satellite dish installed in the flat, thus everyday I was able to observe the comments and reactions of my informants on the political and social news and events from Poland. Therefore, I got used to hearing about all the political thieves, who instead of governing the country properly, are stealing the nation, and that it is politicians who are the reason for their 'being in the exile'. It seemed relevant for me to make notes that concern the language figures and words, which my informants used to criticize Polish state officials. Consequently, I have noticed 
the elements of 'cultural intimacy', which is a significant aspect of the anthropology of nationalism. Michael Herzfeld points out that 'cultural intimacy' may be recognised and examined during a long anthropological fieldwork. It reveals itself in the micro-contexts of daily situations and is a vehicle for explaining the interaction between the individuals and the state officials. As the author asserts, 'cultural intimacy' involves

$[\ldots]$ the recognition of those aspects of cultural identity that are considered a source of external embarrassment but that nevertheless provide insiders with their assurance of common sociality, the familiarity with the bases of power that may at one moment assure the disenfranchised a degree of creative irreverence and at the next moment reinforce the effectiveness of intimidation' (Herzfeld 2004: 3).

The concept of 'cultural intimacy' involves an intimate language and a sort of national figures and stereotypes, that are recognized in the public discourse and simultaneously used by the individuals and the state officials. In my opinion, however, 'cultural intimacy' is even more visible during the fieldwork conducted among any immigrants that perceive themselves as having been forced into 'exile'. In the context of Polish immigrants workers it is clear that 'cultural intimacy' is engaged in the pragmatic aspect of political negligence and a symbolic figure of 'road building'. Namely, in Poland, there is a timeless public debate related to the unexplainable problems with transport and infrastructure. It is not important if the government is left or right-winded, the problem with roads remains the same. It has already been so irritating for nationals that it became a common element of everyday jokes. Obviously, it occurred also during my interviews with Polish immigrant, especially in the context of comparisons of Poland and Norway, which on the other hand were very often among my informants. Therefore, I remember talking about 'the roads' issue with Paweł, a 38-years old man, who has been working in Oslo for almost 7 years now. It seemed that his favourite subject is the constant critique of the Polish officials for not doing what they should do to govern the country properly. For Pawet, the politicians were merely thieves, who should be put in jail or punished by cutting their salaries to minimum wage. Hearing all the complaints, I consciously decided to ask him about the 'the roads' issue. Obviously that made him even more anxious. He almost yelled at me that it is unbelievable that the roads cannot be simply built and that their conditions are worse than poor. Immediately, he started the comparison of Norwegian and Polish workers and working praxis. Therefore, I have been briefly introduced to the basic differences in working habits and skills between two nations. It was significant for 'cultural intimacy' because, as my informant said, Norwegians work hard day and night building the roads, while Poles only pretend to work hard. In fact, Paweł described this attitude in terms of 'the Polish worker's mentality'. This obviously 'general figure' comes from the communist period and connotes relatively high social status of the workers, which allowed them to cross social and cultural boundaries without being sanctioned. In the context of 'cultural intimacy' it is significant that Paweł uses this figure simultaneously to criticize the workers that build the roads and also to justify his working habits as an immigrant in Norway. He explained me that it is economically better to work longer, even if the job is easy and could be done quickly. Obviously while introducing me to the different ways and systems of avoiding the detection of laziness, he was constantly using the 'general figure' of 'the Polish worker's mentality'. Lucidly, there was nothing paradoxical in his way of thinking and acting. After all, 'cultural intimacy' has a huge impact on individual's perception of the world, despite it usually not being visible initially. 
It seemed that the national identity was a sort of core in the everyday life of my informants. It preserved the constant sense of nation belonging and the immanency of the specific daily routine. As Michael Billig asserts:

It is argued that these habits are not removed from everyday life, as some observers have supposed. Daily, the nation is indicated, or 'flagged', in the lives of its citizenry. Nationalism, far from being an intermittent mood in established nations, is the endemic condition (Billig 1995: 6).

Therefore, the ideology of banal nationalism and 'cultural intimacy' were lucidly exposed by national symbols, myths and metonymic figures, which in turn, kept the intensity of particular immigrant's social and cultural praxis.

\section{"NORWAY IS LIKE A HOSPITAL." THE PRAGMATISM OF WORKING AND LIVING}

In general, whilst being in Norway I experienced a sort of cultural and national paradox. The Polish space created and organized by the immigrants was very resistant to most aspects of Norwegian reality. A microcosmic immigrant homeland seemed to satisfy my informants and give them a sense of similarity and familiarity. After all, while the individual deals with the 'unknown' and 'unpredictable', it seeks a specific sense of community belonging. This very phenomenon was often encountered during the casual conversations and ethnographic interviews with my informants. I regularly asked them about the reasons and causes of leaving Poland and coming to Norway. I was also curious about their sentiments and nostalgias as well as the meaning of being Polish in the context of Norwegian reality.

I remember a crucial conversation with Rafał, a 30-year old man, who had been working in Norway for over 7 years. We were sitting in the kitchen, while Rafał was telling me that he used to live in Norway with his family. However, after a few years they had decided to return to Poland and not to 'mess' with their son's identity, who had just started the Norwegian school. We also talked about his first impressions of Norway and it quickly struck me as it was a significant ethnographic detail that cast new light and perspective on immigrants' everyday life. Namely, Rafał used an important metaphor that described his ambiguous Norwegian experiences.

You know - he said to me, while lying comfortable on the bed - I will tell you this. When I came here for the first time, I don't know why, but I had this strange feeling like I was in a hospital or something. And you know... when I'm in a hospital I feel very uncomfortable... I'm trying to avoid everything that surrounds me. For example, I'm trying not to touch the banisters, because of all the bacteria. And this is what I felt that time... the time when I came here to work.

Obviously, the hospital metaphor is very significant in the context of his daily routine. The hospital, however, is not an ordinary space. In fact, it may be described in Michel Foucault's terms of inclusion and exclusion. Therefore, the hospital may be interpreted as a heterotopic space that is either closed or open for the individual. In other words, the place that the individual usually attempts to avoid and neglect and to which the individual only goes through necessity. Thus, in the context of banal nationalism and national identity performing, the hospital metaphor connotes the significant contents. 
Therefore, the little immigrant homeland created by my informants seems to be a pragmatic vehicle for dealing with all that is 'unknown', 'different' and, in this case, 'hospital' in Norwegian reality. The Polish immigrants accustomed and negotiated the social and cultural reality in the ways that occurred to them be the most 'natural' and 'safe'. Consequently, Norway seems to be only a pragmatic space of pragmatic expectations among most of the immigrants. It is like a 'hospital' - needed only when it helps, namely gives work opportunity and higher salaries. Thus, the Polish immigrants routinely finish their work hours and go back to rented flats or rooms which resemble Polish homes and watch Polish news channels, prepare Polish meals and meet their families online.

It is not a banal reflection, as one may assume. Obviously, the economic pragmatism drives the immigrants in everyday life and furthermore is a general reason of their exile. Yet, treating and perceiving Norway only in the context of transient and pragmatic necessity imply serious problems related to daily existence and interaction with Norwegian society. The Polish immigrants among whom I have conducted a fieldwork are not common immigrants. Most of them have not decided yet, if they want to stay in Norway permanently or rather return to Poland. They more resemble migrants, whose identity is torn between two different national realities due to the continual movement. My informants repeatedly told me that they would soon return to their families and leave their miserable life 'in exile'. In fact, I have quickly realised that such definitive returns are constantly postponed to the next month or the next year. Consequently many of them live and work in Norway illegally for several years. After all, why should one bother to legitimize a temporary stay when a work permit involves lots of paper work? Why should one bother to engage in any deeper interactions with Norwegians, while it requires language? It is more profitable to stay focused on work and to interact with other Polish immigrants.

There is also a significant aspect of the immigrants' identity dilemma, which may occur in the context of frequent traveling between Norway and Poland. Budget airlines provide an easy opportunity to visit families and friends back home. Therefore, my informant Rafat is back in Poland once a month, just to take a break, rest a little and relax. The crucial issue is that it puts the individual at the risk of the constant redefinition of social status and symbolic capital. Working and living in Norway economically costs a lot and involves sacrifices, while being in Poland affords the individual the social status of relatively rich person. The individual may afford then to buy a dinner in an expansive restaurant and take the family on an exotic holiday. Pierre Bourdieu would put it in the terms of 'symbolic wars' between individual's different capitals and the ones constructed by the society. However, in the context of immigrants, the constant process of shifting from a low standard of living in Norway to the high one in Poland may cause serious individual identity struggle, general frustration and distaste issues.

It occurred to me that the number of immigrants that mostly act and live like my informants in Tveita is high, so I decided to speak about them with Polish state officials in Oslo. I thought that it may be crucial for my fieldwork to gather some data and different perspectives on the matters from the Polish consulate or embassy. However, after a short visit and conversation with the Polish consul, I was indirectly informed that the 'new' economic immigration is not a major issue to be dealt with. It is hard to count them as well as to get to them, thus means of interaction are very narrow. Conversely, the immigrants themselves do not want to interact with the officials, usually due to their illegal employment status. There is, however, cooperation between the consulate and 
the established 'old' group of Polish immigrants most of whom are political refugees mainly related to the 'Solidarity' movement of the 1980's. It seems that the contemporary economic immigrants are in a way neglected and that there is no great need to be involved with them, even though they represent the majority of all the Poles in Norway.

There are also non governmental civil initiatives aimed at helping Polish immigrants and promoting Polish culture in Norwegian society - Związek Polaków w Norwegii (Den Polske Forening i Norge, Association of Poles in Norway) and Klub Dyskusyjny Polaków w Norwegii (Den Polske Klubben i Norge, Polish Discussion Club in Norway) are probably the two most known organizations. However, for the Polish immigrants, it is the Catholic Church that plays a significant role in their 'exiled life'. Therefore, every Sunday a great number of Poles attend the masses that are conducted by Polish priests in San Hallvard and San Olav church. After all, the perception of Poles as being very religious and engaged in their faith appears to be challenged by the reality of Norway. My informants however told me that religion is of secondary importance among all the Polish immigrants, and that they themselves do not practice. Nevertheless, I decided to check it by attending the Polish masses. It quickly occurred to me that it was not merely faith and religion that keep the immigrants practicing, but more the social aspect of every Sunday ritual. The meetings and gatherings before and after the mass, sharing cigarettes, or drinking coffee, were great opportunities to exchange news, gossips or practical tips, clues and guides. Consequently, I have noticed a sort of immigrant knowledge and experience exchange, which pointed me towards the significant process of 'immigrant enculturation'.

\section{THE "IMMIGRANT ENCULTURATION"}

I experienced a lucid example of 'immigrant enculturation' during one of the meetings that was organised by the Catholic Church and NAV (Norwegian Labour Administration Office) after a Sunday mass in St. Hallvard church. The purpose of the meeting was to relay the basic information that concerns Norwegian labour laws and social welfare. The meeting was conducted by a NAV employee who spoke fluent Polish, while all the key words screened on the board were in Norwegian. For the anthropologist focused on the immigrants issues, the significant details were not merely those related to the administrative and formal matters of NAV policy, but also their particular interpretations, as well as general questions and comments that emerged from the Poles during the meeting. The latter aspect, moreover, occurred to be significant in the terms of 'immigrant enculturation'. There were so many questions raised among the newcomers that the moderator could not keep up with the answers. Obviously, the reason for that was not the lack of competence of the moderator, but rather the helpfulness and resourcefulness of the gathered immigrants. Apparently, most of them have already experienced some of the publicly raised issues, therefore, they were eager to share their own personal thoughts and reflection as well as the practical clues and guides for particular solutions among the whole crowd. Consequently, the formal meeting organised by NAV, transformed into a sort of casual gathering of Polish immigrants.

However the 'immigrant enculturation' starts much earlier, before one even comes to Norway. Obviously the reason for that is the contemporary world of fast media and 
communication. The latter seems on the other hand to be a crucial vehicle for relaying and achieving the immigrant knowledge, habits and praxis. Numerous websites and social network communities are an excellent space for exchanging different immigrant experiences as well as tips, clues and any other practical information that concern living and working in a particular country. In the context of Poles coming to work in Norway, the most popular and active website is fourumnorwegia.net. One may find here comments, opinions, questions and needs which are crucial for anyone who has decided to come to Norway and consequently becomes an economic immigrant. The more experienced immigrants are always eager to share their knowledge with newcomers, even though some of the guides may be misleading. Therefore, one may find out the best location to rent a flat; how much it costs; what deposit is required and why it has to be paid. One may also rent a flat from a fellow countryman, who is just about to go on holidays back to Poland and is eager to rent it for NOK 3500 per month. This is also the most common way of finding the accommodation, however, living among national next of kin seems always easier to cope. Obviously, there are also job offers - mainly in construction field, and an interesting social column, where one may find ads related to sponsoring and prostitution. The Internet social network is merely the beginning of a wider and more complex process that continues to follow. As Thomas Hylland Eriksen points out,

Many migrant populations are forced to establish webs of security and trust independently of the state in which they live, creating stable minorities with distinct identities (Eriksen 2007: 95).

Therefore, the imagined immigrant community gradually starts to spread among the individuals. One knows what to do and where to go in the different social and cultural reality, however, while being in exile is expected to follow the lead of those who are already skilled and far more experienced. Hence, the very first days of every newcomer immigrant arrival may be perceived in the terms of specific ways of absorbing the knowledge and skills from the experienced ones. Therefore, the immigrant community is not merely an issue of superficial bound, but also a specific state of mind and a way of acting. The national sentiment that drag the individual into the game of symbols and myths is indirectly constructing the pragmatic network of relations as well as social and cultural arrangements. In general, due to the process of the 'immigrant enculturation' the individual may achieve the particular knowledge that may be helpful to deal with the immigrant reality, but simultaneously limits the context of one's interpretation and negotiation of the very reality.

Anthropology may cast a brand new light on the phenomena that are believed to be 'obvious' and 'known'. The inside anthropological perspective reveals the significant role of the context of everyday life praxis and casual conversations that are loaded with symbolic performances, actions and narrations. Therefore, in the context of Polish immigrants in Oslo, it is not merely the economic side and the labour practice, but also the whole cultural and national background that has a huge influence on the sphere of interactions with Norwegian society, even though they seem to be pragmatic. 
Consequently, while conducting the fieldwork, I have experienced a constant process of reconstructing the nationhood among my informants. As it was already mentioned, the reasons for that were various, but they had one common factor, the power of nation and national identity in the contemporary world. Thus, the nationality, even though is socially and culturally constructed, is commonly believed to be immanent sphere of individual need for community. Thomas Hylland Eriksen asserts:

Migration can be an unsettling, confusing and frustrating experience, especially if it is prompted by 'push' factors rather than 'pull' factors. Immigrants are often ostracized by the majority and denied full civic rights by the governments. Many respond by devising both lo$\mathrm{cal}$ and transnational strategies strengthening the coherence of their local community and networks, often based on ethnicity or religion, as well as their ties to the countries of origin (Eriksen 2007: 93).

Therefore, the process of reconstructing the nationhood among Polish immigrants may be perceived as an elementary vehicle for everyday existence while being in 'hospital Norway'.

\section{REFERENCES}

Bauman Zygmunt. 2000. Liquid Modernity. Cambridge: Polity Press.

Billig Michael. 1995. Banal nationalism. London - Thousand Oaks - New Delhi: SAGE Publications.

Eriksen Thomas Hylland. 2007. Globalization. The Key Concepts. Oxford - New York: Berg.

Geertz Clifford. 2001. Available Light: Anthropological Reflections on Philosophical Topics.

Princeton: Princeton University Press.

Herzfeld Michael. 2004. Cultural Intimacy: Social Poetics in the Nation-State. London New York: Routledge.

Kristeva Julia. 1993. Nations Without Nationalism. New York: Columbia University Press.

"NORWAY IS LIKE A HOSPITAL." VEHICLES FOR (RE-)CONSTRUCTING

THE NATIONHOOD AMONG POLISH IMMIGRANTS IN OSLO

\section{Summary}

The article is a general anthropological survey of the complex issues of Polish diaspora in Norway. The reflections and interpretations are based on the fieldwork conducted by the author among Polish economic immigrants in Oslo during the summer of 2009 for the interdisciplinary academic project CULCOM ('Cultural Complexity in the New Norway'). The main goal of the fieldwork was to examine the tools for reconstructing the nationhood in immigrants' everyday life, as well as the particular nationalism shaped via social and economic class, gender relations and particular cultural background. The present article, however, focuses only on the first issue. Therefore, it deals with the most banal aspects of immigrants' daily routine which at the first glance seem to be irrelevant and less important. Yet, by using anthropological perspective one may observe that the same 
daily practices involve various and complex moments of national identification. As a result, the article describes and analyzes the national praxis of Polish immigrant workers living in one of the Oslo districts. What seems to be interesting is the specific process of constructing the hermetic and national space by the immigrants in the context of Norwegian reality. This process, in turn, includes various tools for banal nationalism.

Keywords: banal nationalism, immigrants, Polish diaspora, Oslo, Norway

\section{"NORWEGIA JEST JAK SZPITAL". (RE-)KONSTRUKCJA TOŻSAMOŚCI NARODOWEJ POLSKICH IMIGRANTÓW W OSLO}

\section{Streszczenie}

Artykuł jest ogólnym spojrzeniem na problematykę polskiej diaspory w Norwegii. Podstawą refleksji są badania antropologiczne przeprowadzone przez autora wśród polskich imigrantów ekonomicznych w Oslo latem 2009 roku w ramach interdyscyplinarnego projektu CULCOM („Cultural Complexity in the New Norway"). Głównym celem badań terenowych była zarówno analiza procesów rekonstrukcji tożsamości narodowej w życiu codziennym imigrantów, jak i próba spojrzenia na fenomen nacjonalizmu w kontekście kategorii społeczno-kulturowych (takich, jak klasa społeczna, gender itd.).

Sam artykuł natomiast podejmuje różne, banalne wręcz kwestie codzienności polskich imigrantów, które jednak po dokładniejszej analizie ukazują wielość i złożoność procesów tożsamościowych. W konsekwencji, opisana i zinterpretowana została tu narodowa praxis polskich robotników budowlanych zamieszkujących jedną z dzielnic Oslo. Istotne wydaje się tutaj tworzenie przez moich informatorów hermetycznej, narodowej przestrzeni w kontekście norweskiej rzeczywistości, w której można zauważyć wiele narzędzi i praktyk banalnego nacjonalizmu. 